\title{
THERMAL ANALYSIS OF COPPER AND CHROMIUM ALLOY, COPPER AND ALUMINIUM SOLAR ABSORBER
}

\author{
Premkumar $\mathbf{M}^{1}$, Ramachandran $\mathbf{S}^{2}$ \\ ${ }^{1}$ Research Scholar, Department of Mechanical Engineering, Sathyabama University, India \\ ${ }^{2}$ Department of Mechanical Engineering, Sathyabama University, India
}

\section{Abstract}

In the solar chimney solar collector plates are used for heating up the ambient air. Increase in the temperature of the air inside the chimney increases the efficiency. Thus the solar absorber selected plays an important role in the efficiency of the solar chimney. In this paper the heat transfer analysis is done for solar absorbers like aluminium, copper and copper chromium alloy using ANSYS. The fluid dynamics analysis helps us to select the optimum sollr absorber. the analysis of various solar collector plates ,the nodal temperature of the copper chromium plate is compared with the copper and aluminium plates. The heat transfer and thermal conductivity of the copper chromium plate is compared with copper and aluminium plates

\section{INTRODUCTION}

The solar collecting material used in this solar chimney is copper and chromium alloy. Copper and Chromium is a heat treatable alloy offering good electrical conductivity, resistance to softening at elevated temperatures and good strength and hardness[1]. This combination of alloy absorbs more solar energy when compare with other materials. It is also preferred for resistance welding electrode materials for a variety of applications. Nominally composed of $99.1 \%$ copper and $0.9 \%$ chromium, this heat treatable alloy can be brought to its softest condition by annealing it at $1000 \$ \mathrm{C}(1850 \$ \mathrm{~F})$ for one-half hour at temperature, then rapidly quenching it in water[3]. In this annealed condition, the alloy is ductile and easily formed, and has an electrical conductivity of about $40 \%$ IACS and its chemical composition is Cu: $98.80-99.40 \%$, Cr:0.60 - $1.20 \%$.

TABLE 1

MECHANICAL PROPERTIES OF COPPER -CHROMIUM

\begin{tabular}{|c|c|c|}
\hline Hardness & Rockwell B Scales & 70 \\
\hline Tensile Strength & $\mathrm{N} / \mathrm{mm}^{2}$ & 482.633 \\
\hline Yield strength & $\mathrm{N} / \mathrm{mm}^{2}$ & 379.211 \\
\hline Elongation & $\mathrm{cm}$ & 4.2 \\
\hline
\end{tabular}

TABLE 2

PHYSICAL PROPERTIES OF COPPER -CHROMIUM

\begin{tabular}{|c|c|c|}
\hline Thermal Conductivity & $\mathrm{W} / \mathrm{m} . \mathrm{K}$ & 26.97 \\
\hline Specific Heat & $\mathrm{J} / \mathrm{Kg} . \mathrm{K}$ & 376.8 \\
\hline Density & $\mathrm{Kg} / \mathrm{m}^{3}$ & 5.14 \\
\hline Modulus of Elasticity & $\mathrm{N} / \mathrm{mm}^{2}$ & 117210.90 \\
\hline
\end{tabular}

\section{THERMAL ANALYSIS FOR COPPER CHROMIUM PLATE}

Thermal analysis is a general term used to describe analyses where the results quantities include stresses and strains. It is also known as thermal analysis. The properties of the copper plate is taken as follows: Thermal conductivity is $187 \mathrm{~W} / \mathrm{mk}$, Specific heat is $0.095 \mathrm{KJ} / \mathrm{Kgk}$, Density is $0.321 \mathrm{~kg} / \mathrm{m}^{3}$ [6]. The Mesh Size that is the number of element divisions is 0.1 ."

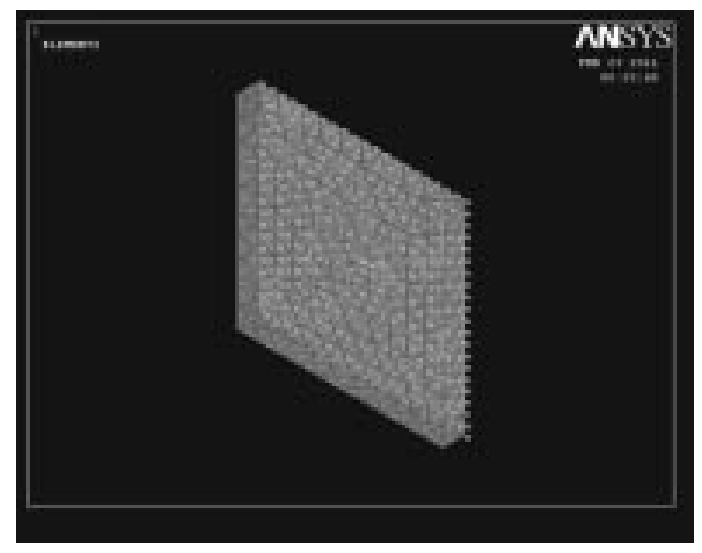

Fig.1. Solution of Temperature Model for Cu-Cr Plate 


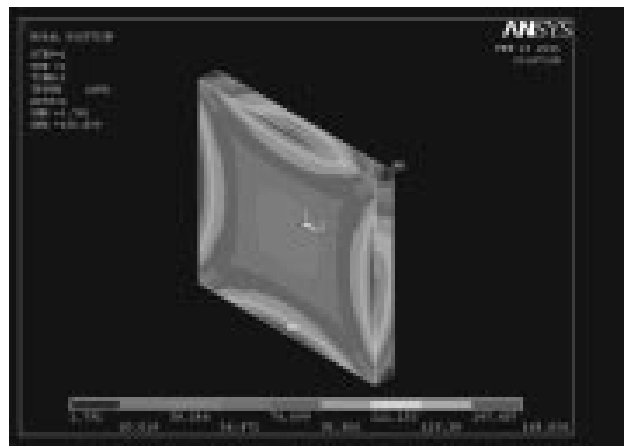

Fig. 2. Nodal Temperature For $\mathrm{Cu}-\mathrm{Cr}$ Plate

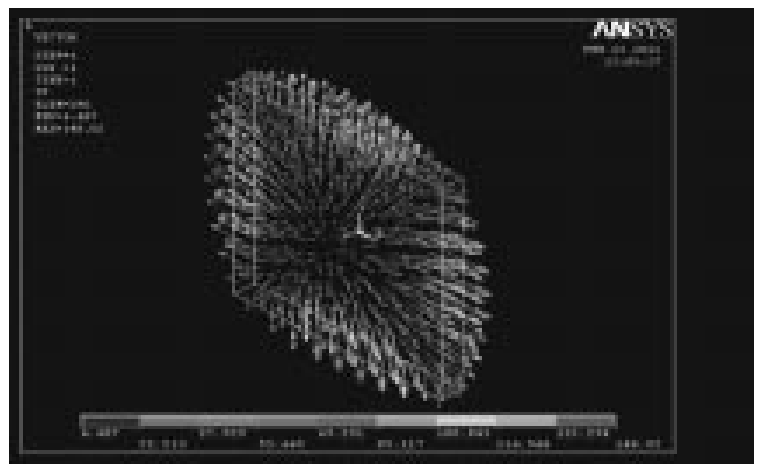

Fig. 3. Vector Plot Heat Transfer for Cu-Cr Plate

The thermal analysis of the copper chromium alloy is shown in the figure.1, $2 \& 3$ from this we can resolve that the maximum nodal temperature of copper chromium alloy is $180^{\circ} \mathrm{C}$ and the heat transfer is about $150^{\circ} \mathrm{C}$

\section{THERMAL ANALYSIS FOR COPPER PLATE}

The properties of the copper plate is taken as follows: Thermal conductivity is $231 \mathrm{~W} / \mathrm{k}$,Specific heat is $0.095 \mathrm{KJ} / \mathrm{Kgk}$, Density is $0.095 \mathrm{~kg} / \mathrm{m}^{3}$. [8]. The Mesh Size that is the number of element divisions is 0.1 ".

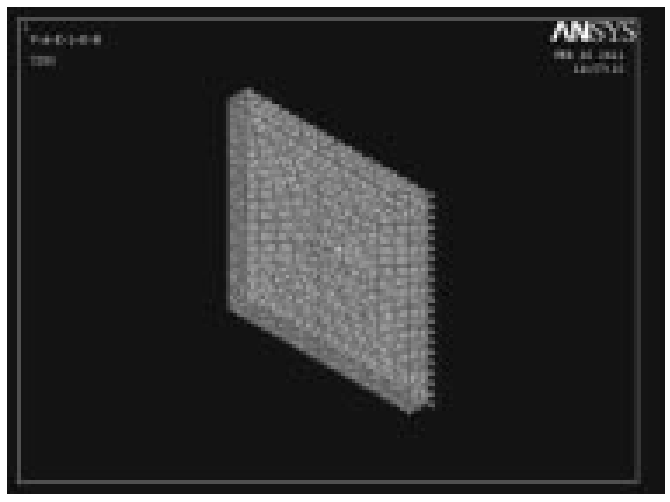

Fig.4. Solution of Temperature Model For Cu Plate

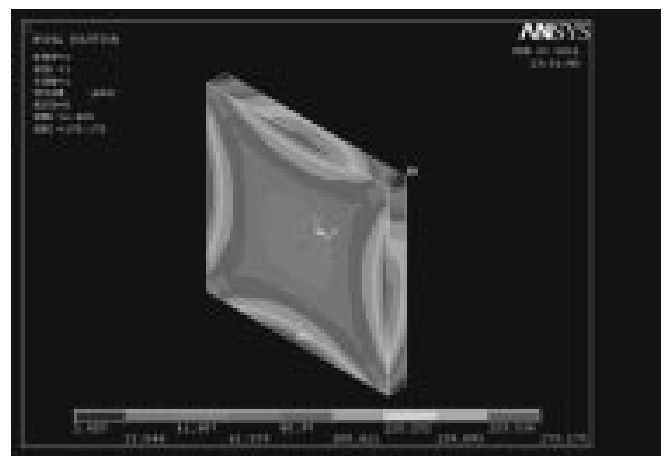

Fig. 5. Nodal Temperature For Cu Plate

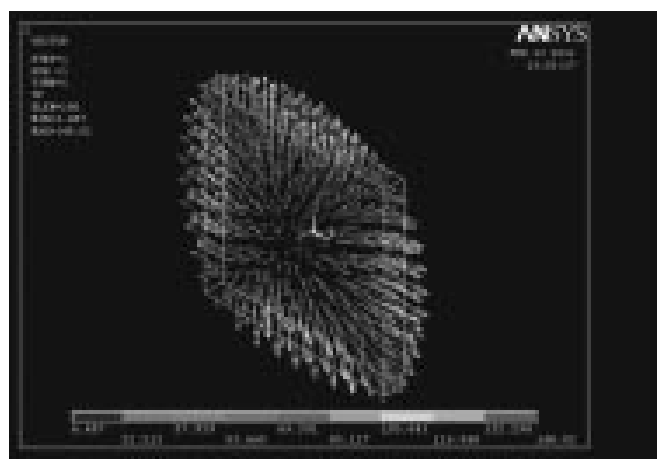

Fig. 6. Vector Plot Heat Transfer For Cu Plate

The thermal analysis of the copper is shown in the figure. $4,5 \& 6$ from this we can resolve that the maximum nodal temperature of copper is $165^{\circ} \mathrm{C}$ and the heat transfer is about $135^{\circ} \mathrm{C}$.

\section{THERMAL ANALYSIS FOR ALUMINIUM PLATE.}

The properties of the aluminium plate is taken as follows:Thermal conductivity is $136 \mathrm{~W} / \mathrm{mk}$,Specific heat is $0.098 \mathrm{KJ} / \mathrm{Kgk}$, Density is $0.24 \mathrm{~kg} / \mathrm{m}^{3}$. The Mesh Size that is the number of element divisions is 0.1 ".

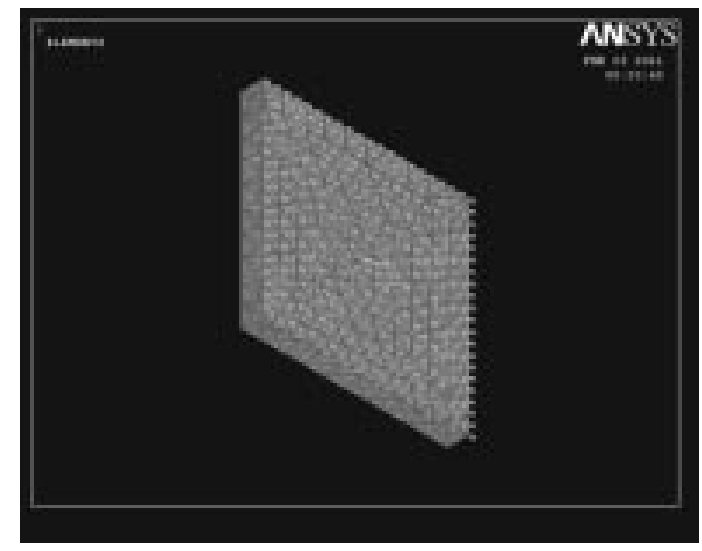

Fig.7.Solution of Temperature Model For Al Plate 


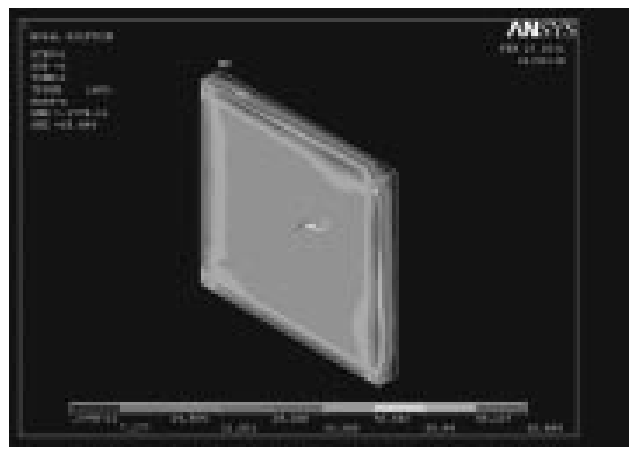

Fig. 8. Nodal Temperature for Al Plate

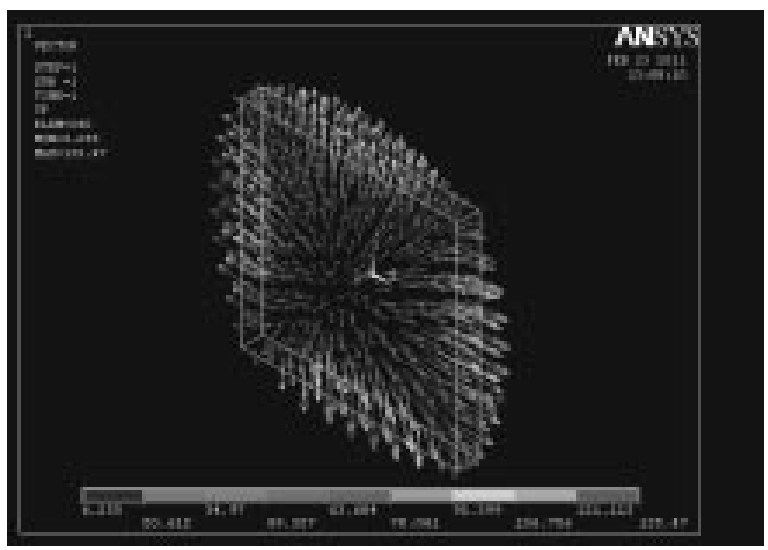

Fig. 9. Vector Plot Heat Transfer For Al Plate

The thermal analysis of the aluminium is shown in the figure $7,8 \& 9$ from this we can resolve that the maximum nodal temperature of aluminium is $65^{\circ} \mathrm{C}$ and the heat transfer is about $40^{\circ} \mathrm{C}$.

TABLE 3

\section{Comparison of Analysis off Various Solar Collector Plates}

\begin{tabular}{|c|c|c|}
\hline & $\begin{array}{c}\text { Nodal } \\
\text { temperature } \\
\left({ }^{\circ} \mathrm{C}\right)\end{array}$ & $\begin{array}{c}\text { Vector } \\
\text { temperature } \\
\left({ }^{\circ} \mathrm{C}\right)\end{array}$ \\
\hline Copper chromium & 179.175 & 148.02 \\
\hline COPPER & 165.834 & 135.47 \\
\hline ALUMINIUM & 65.494 & 40.839 \\
\hline
\end{tabular}

The figure.10. and the table.III shows the comparison of analysis of various solar collector plates. The nodal temperature of the copper chromium plate is very higher when compare with the copper and aluminium plates.

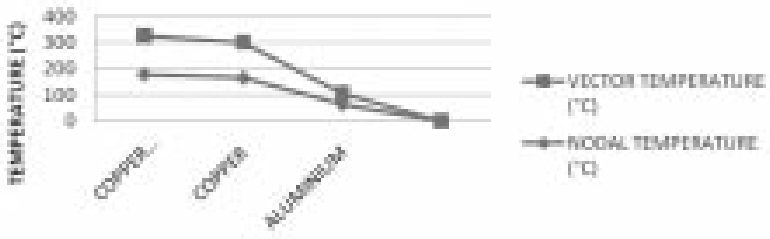

Fig. 10.Comparison Of Analysis Of Various Solar Collector Plates

Nodal Temperature

$=\left(\mathrm{Cu}-\mathrm{Cr}\left(179.175^{\circ} \mathrm{C}\right)>\mathrm{Cu}\left(165.834^{\circ} \mathrm{C}\right)>\mathrm{Al}\left(65.494^{\circ} \mathrm{C}\right)\right.$

The heat transfer in the copper chromium plate is very high and its thermal conductivity is more when compare with copper and aluminium plates

$$
\begin{aligned}
& \text { Heat Transfer } \\
& =\mathrm{Cu}-\mathrm{Cr}\left(148.02^{\circ} \mathrm{C}\right)>\mathrm{Cu}\left(135.47^{\circ} \mathrm{C}\right)>\mathrm{Al}\left(40.839^{\circ} \mathrm{C}\right)
\end{aligned}
$$

When Comparing the nodal temperature and heat transfer of the three plates the copper chromium plate has higher heat transferring capacity and thermal conductivity.So we selected the copper chromium plate as the solar collector or solar absorber for the solar chimney.

\section{RESULT AND CONCLUSION}

When comparing the analysis of various solar collector plates,the nodal temperature of the copper chromium plate is very higher when compare with the copper and aluminium plates. The thermal analysis of the copper chromium alloy is shown in the figure.1, 2 \& 3 from this we can resolve that the maximum nodal temperature of copper chromium alloy is $180^{\circ} \mathrm{C}$ and the heat transfer is about $150^{\circ} \mathrm{C}$. The thermal analysis of the copper is shown in the figure.4, $5 \& 6$ from this we can resolve that the maximum nodal temperature of copper is $165^{\circ} \mathrm{C}$ and the heat transfer is about $135^{\circ} \mathrm{C}$. The thermal analysis of the aluminium is shown in the figure.7, $8 \& 9$ from this we can resolve that the maximum nodal temperature of aluminium is $65^{\circ} \mathrm{C}$ and the heat transfer is about $40^{\circ} \mathrm{C}$.

Nodal Temperature of $\mathrm{Cu}-\mathrm{Cr}$ alloy is $179.175^{\circ} \mathrm{C}$ which is greater than that of copper and aluminium.

The heat transfer in the copper chromium plate is very high and its thermal conductivity is more when 
compare with copper and aluminium plates. The Heat Transfer of Cu- $\mathrm{Cr}$ is $148.02^{\circ} \mathrm{C}$ which is greater than that of copper and aluminium. So we selected the copper chromium plate as the solar collector or solar absorber for the solar chimney design.

\section{REFERENCES}

[1] Sakonidou E.P., Karapantsios T.D., Balouktsis A.I., Chassapis D., Modeling of the optimum tilt of a solar chimney for maximum air flow Pages 80-94.

[2] Theodor W. von Backström, Thomas P. Fluri, Maximum fluid power condition in solar chimney power plants - An analytical approach, Pages 1417-1423 [3] Tripanagnostopoulos, Y. Siabekou, Ch. , Tonui, J.K. , The Fresnel lens concept for solar control of buildings, Solar Energy, 81 (5), p.661-675, May 2007.

[3] Fluri T.P., Von Backström T.W., Performance analysis of the power conversion unit of a solar chimney power plant, Pages 999-1008 [5] dos S. Bernardes, M.A. / Vosz, A. / Weinrebe, G. , Thermal and technical analyses of solar rchimneys ,Solar Energy, 75 (6), p.511-524, Dec 2003.
[4] Bansal, N.K. / Mathur, J. / Mathur, S. / Jain, M. , Modeling of window-sized solar chimneys for ventilation Building and Environment, 40 (10), p.1302-1308, Oct 2005.

[5] Hatami, N., Bahadorinejad, M., Experimental determination of natural convection heat transfer coefficient in a vertical flat-plate solar air heater Solar Energy, 82 (10), p.903-910, Oct 2008.

[6] Jannot, Y., Coulibaly, Y. The evaporative capacity" as a performance index for a solar-drier, air-heater, Solar Energy, 63 (6), p.387-391, Dec 1998.

[7] Mohanraj, M. , Chandrasekar, P. , Drying of copra in a forced convection solar drier ,Biosystems Engineering, 99 (4), p.604-607, Apr 2008.

[8] Gupta, M.K. , Kaushik, S.C. , Exergetic performance evaluation and parametric studies of solar air heater Energy, 33 (11), p.1691-1702, Nov 2008.

[9] Zhai, X.Q. / Dai, Y.J. / Wang, R.Z. Experimental investigation on air heating and natural ventilation of a solar air collector, Energy and Buildings, 37 (4), p.373-381, Apr 2005 